\title{
Biogeography of the Decapod and Stomatopod Crustacea of the Tropical Pacific: Issues and Prospects ${ }^{1}$
}

\author{
Foseph Poupin ${ }^{2}$
}

\begin{abstract}
Biogeographic patterns of the Crustacea (Decapoda and Stomatopoda) are given for the tropical Pacific, based on recent taxonomic studies combined with emergence of regional databases. Conclusive results are still difficult to obtain due to incomplete regional inventories and existence of complexes of sibling species with unclear taxonomic status. A time-series graph of the number of new records plotted against time is computed for several central Pacific islands (French Polynesia, Pitcairn, Easter Island, and Clipperton). It demonstrates that the fauna is still insufficiently known in those places. A biodiversity gradient is calculated for several taxa between West and East Pacific. The traditional decrease between Australia and French Polynesia is confirmed for higher taxa (Brachyura, Anomura), but at lower taxonomic levels it is not always verified (e.g., hermit crabs, Calcinus; crabs, Trapezia). A map is presented illustrating the following provisional biogeographic results: (1) cryptic endemic species recognized in the Marquesas Islands; (2) presence of a distinct faunistic province in the South Pacific, along the $25^{\circ} \mathrm{S}$ parallel, including Rapa and Easter Islands; (3) theoretical position of the border between the Indo-West Pacific (IWP) and East Pacific (EP) faunistic provinces $\left(84^{\circ} \mathrm{W}\right.$ on the seamounts of Sala $\mathrm{y}$ Gómez/Nazca and $110^{\circ} \mathrm{W}$ on Clipperton); (4) differences between Clipperton, with a mixed IWP-EP fauna (43\% IWP versus $57 \%$ EP species), and the Galápagos, with obvious EP affinities (10\% IWP versus $90 \% \mathrm{EP}$ species).
\end{abstract}

DECAPOD AND STOMATOPOD crustaceans are widespread in the tropical Pacific Ocean and are of special interest for biogeographic studies because their taxonomy is better known than that of other crustacean taxa, as in the case of isopods and amphipods (Poore 2004). This favorable situation is related to the large size and noteworthy coloration of many species and the existence of many ubiquitous species. However, only limited biogeographic studies, such as those of De Grave

1 This is a scientific contribution from Institut de Recherche de l'École Navale, Brest, and Centre de Recherches Insulaires et Observatoire de l'Environment, French Polynesia (CRIOBE) Research Station, Moorea. Manuscript accepted 26 June 2007.

${ }^{2}$ Institut de Recherche de l'École Navale, BP 600, F29240 Brest Armées, France (e-mail: poupin@ecolenavale.fr).

Pacific Science (2008), vol. 62, no. 3:377-383

(C) 2008 by University of Hawai'i Press

All rights reserved
(2001) for pontoniine shrimps or Castro (1999) for the trapeziid crabs, have been conducted for the decapod and stomatopod crustaceans at a Pacific or Indo-Pacific scale. This is in contrast with published results on the biogeography of other taxa in the area: corals (Veron 1993, Glynn et al. 1996), fishes (Robertson and Allen 1996, Randall 1998), and mollusks (Redher 1980).

Progress in taxonomic studies of the decapod and stomatopod crustaceans in the last decades, combined with the emergence of several regional database projects in the $\mathrm{Pa}$ cific region, are promising tools for more refined biogeographic studies. The purpose of this short note is to assess the issues and prospects in the field and to present a few results, based on an inventory made in the central $\mathrm{Pa}$ cific islands (Poupin 2007).

There are, however, two main difficulties: the incomplete and patchy nature of inventories of crustaceans from the Pacific region and the more recent taxonomic studies showing that the many Pacific cosmopolitan spe- 
cies are in fact complexes of sibling species that are difficult to distinguish from each other.

\section{INVENTORIES}

The first difficulty is linked to the more than 1,600 islands that are scattered in a vast marine region and therefore difficult to visit (Motteler 1986). As a result, the inventories of many islands are still incomplete. At present, the best-studied Pacific regions for which updated checklists of species have been recently published are eastern Australia, including the Great Barrier Reef (Davie 2002a,b, Australian Biological Resources Study 2007); Japan (Miyake 1999, Sakai 2004); Guam and the Marianas (Paulay et al. 2003); the Hawaiian Islands (Ahyong 2002a, Eldredge and DeFelice 2002, McLaughlin et al. 2005); French Polynesia (Poupin 1996, 1998, Ahyong 2002b); Easter Island (Poupin 2003); and the "Eastern Pacific outliers"Clipperton (Poupin et al. 2008), Revillagigedo Islands (Hernández Aguilera 2002), and the Galápagos (Garth 1991, Hickman and Zimmerman 2000; unpubl. data). For the Hawaiian Islands there is also an important project by P. Castro and L. G. Eldredge, who are preparing a catalog of the anomuran and brachyuran crabs of the Hawaiian Archipelago, to be published probably as a Special Publication of the Bishop Museum (P. Castro, pers. comm.). The inventories remain incomplete because of sampling difficulties related to the small body size of several taxa (size of cryptochirid crabs is only a few millimeters), the nocturnal behavior of many species, very efficient camouflage (majid and parthenopid crabs), the use of inaccessible burrows (mud shrimps and some alpheids), and deep range situated well beyond the scuba diving limit (homolid crabs from 100 to $1,000+\mathrm{m}$ ). The difficulty in obtaining a comprehensive inventory is illustrated in a time-series graph (Figure 1) compiled from Poupin (2007) for records from French Polynesia, Pitcairn, Easter Island, and Clipperton. Since the first study, made in the Society Islands (GuérinMéneville 1829-1830), the number of records had reached 1,140 species in 2006. Half of this biodiversity was recorded since 1986 , and since then the number of new records has continued to grow with no sign of an asymptote, an indication that the decapods and stomatopods from the area are still insufficiently known.

\section{TAXONOMIC ISSUES}

Another difficulty is linked to the complexity of the taxonomic nomenclature, which renders accurate determination complicated for even qualified taxonomists. Recent fieldwork in the Pacific islands, with increased use of digital cameras and color photography, has revealed that the coloration of crustaceans is crucial for distinguishing sibling species. The use of DNA bar code sequences has confirmed this observation, with the identification of more complexes of sibling species. For example, the large ubiquitous alpheid shrimp Alpheus lottini Guérin-Méneville, 1829, associated with the coral Pocillopora, is recognized as a complex of species based on color pattern and DNA sequences (Williams et al. 1999, Van Wormhoudt 2008), although none is as yet formally described. Because of this situation, the biogeography of the decapods and stomatopods in the Pacific islands can be elucidated only for selected taxa that are sufficiently sampled and have few taxonomic issues.

\section{FIRST RESULTS}

Preliminary biogeographic results are presented in Figures 2 and 3. Figure 2 illustrates the well-known decline of biodiversity that is observed from the west to the east in the $\mathrm{Pa}$ cific. This trend is also known for other taxa, such as the fishes (Randall 1998). On Figure 2, Australian data are from Davie (2002b): Brachyura, 969 species; Anomura, 264 species; Trapezia, 11 species; Calcinus, 19 species. The west-to-east decrease is obvious at the infraorder level, but it has not been verified between Australia and French Polynesia for hermit crabs of the genus Calcinus (20 species in French Polynesia) and crabs of the genus Trapezia (14 species in French Polynesia), both groups strongly associated with coral 


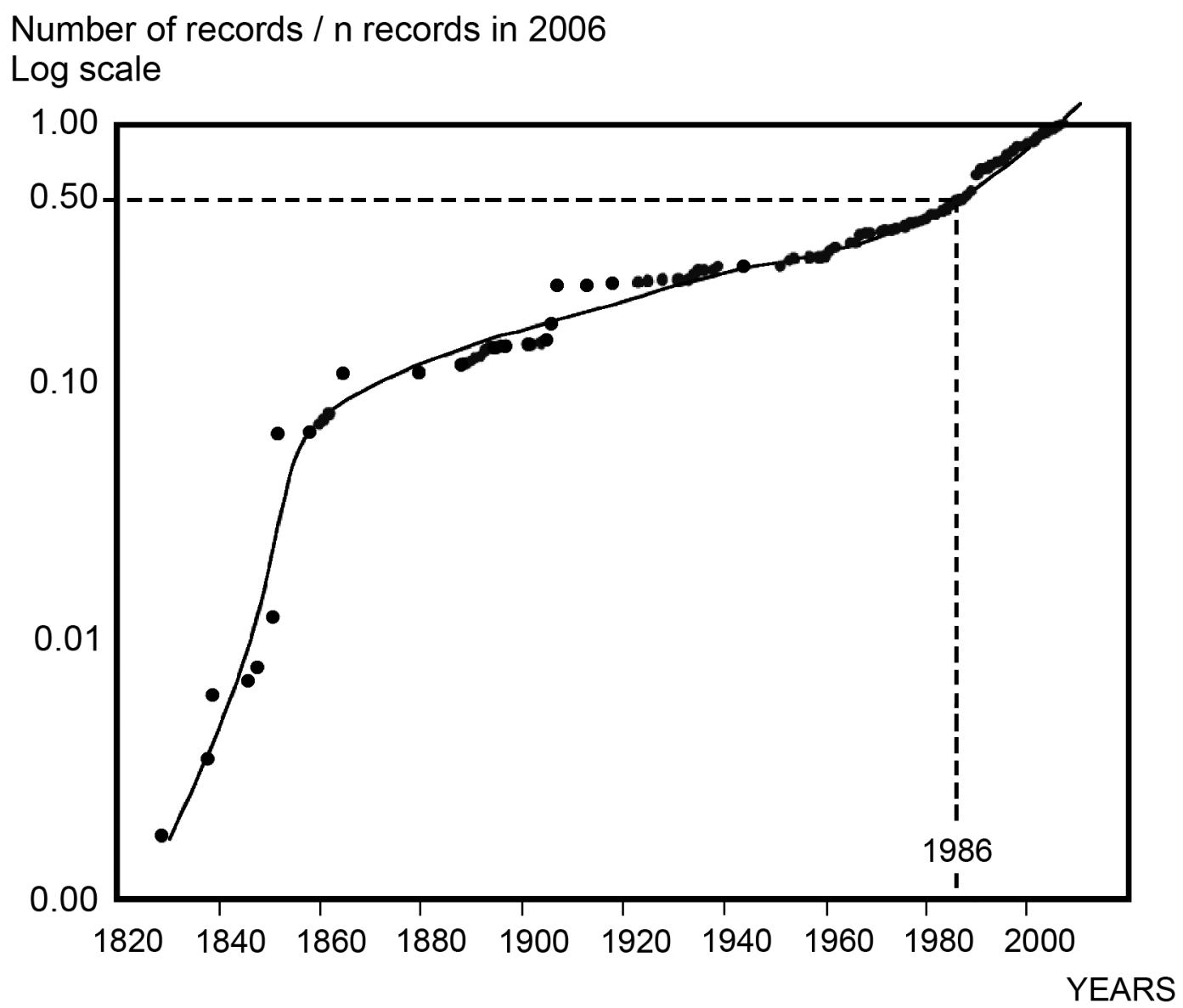

Figure 1. Records of biodiversity (Decapoda and Stomatopoda) from French Polynesia, Pitcairn, Easter Island, and Clipperton between 1829 and 2006. Number of records, on a logarithmic scale, is expressed as a fraction of those known in $2006(n=1,140)$ plotted against time (years). Dashed line shows the point at which half of the 2006 total had been reached (1986).

reefs. This result is attributed to a favorable coral biotope in French Polynesia and demonstrates that the general west-to-east decrease in biodiversity must be verified for each genus.

Few unique faunistic regions are represented in Figure 3. In the Marquesas, taxonomic revisions of diogenid hermit crabs indicate that some endemic species occur there as sibling species of other ubiquitous species: e.g., Calcinus orchidae Poupin, 1997, and Ciliopagurus vakovako Poupin, 1991, instead of Calcinus elegans (H. Milne Edwards, 1836) and Ciliopagurus strigatus (Herbst,
1804), respectively. Additional taxonomic studies may reveal unexpected endemism for that archipelago. The subtropical South $\mathrm{Pa}$ cific (latitude $>25^{\circ} \mathrm{S}$ ) appears as a distinct faunistic region. In those latitudes, lobsters such as Panulirus pascuensis Reed, 1954, and Parribacus perlatus Holthuis, 1967, formerly considered as endemic to Easter Island, are also present in Rapa Island. This indicates that Easter Island should not be considered as a separate faunistic region but must be included as part of a wider region with Rapa I. Rehder (1980) confirmed this tendency for mollusks with several species distributed 


\section{$100 \times$ ( $\mathrm{n}$ species / $\mathrm{n}$ species in Australia)}

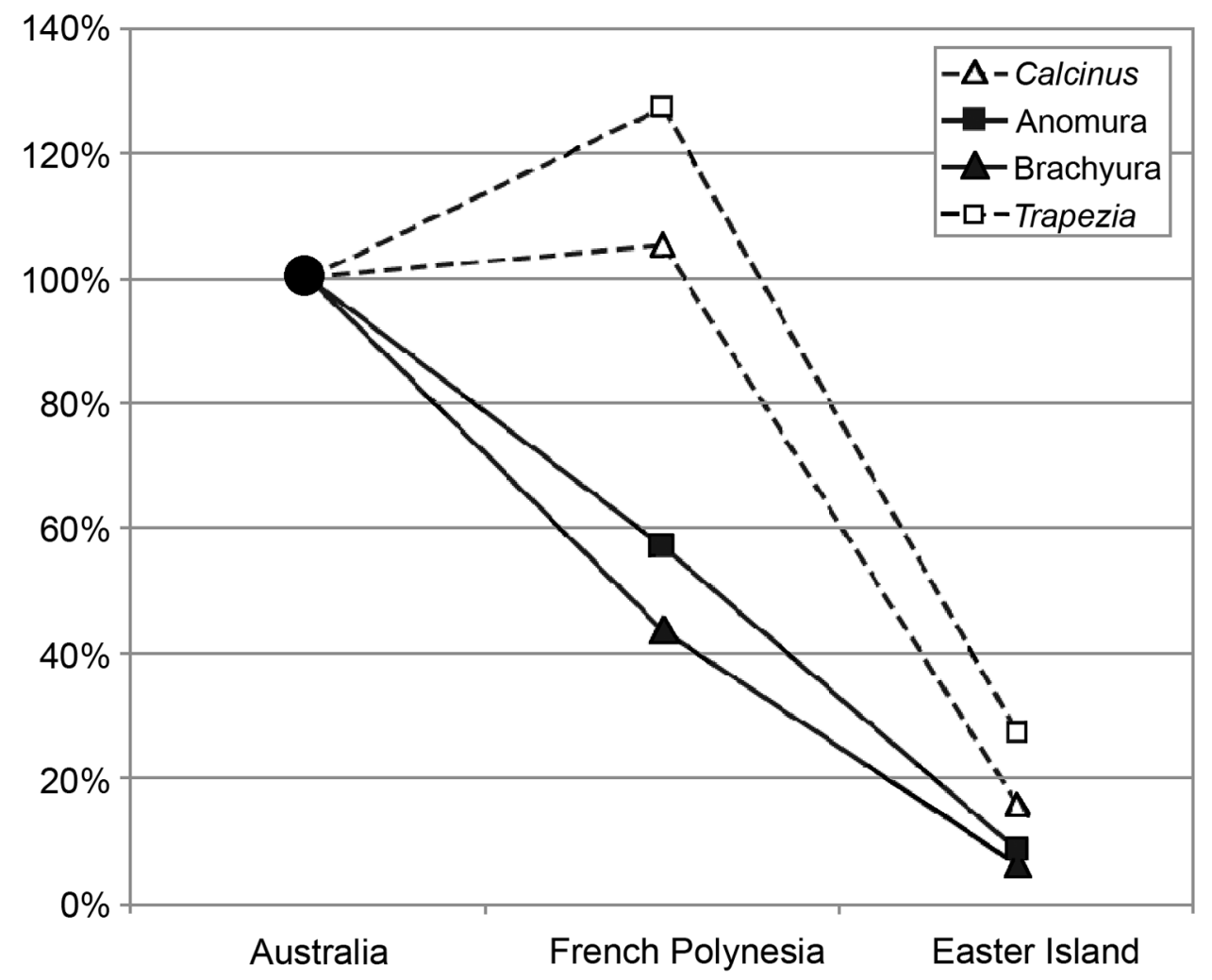

Figure 2. West-to-east gradient in the number of species in the South Pacific, expressed as a percentage of the number of species $(n)$ in Australia. Australian data from Davie $(2002 a, b)$. French Polynesian and Easter Island data from Poupin (2007).

along southern latitudes from Sydney to Easter Island including Norfolk, Kermadec, Rapa, and Pitcairn Islands. Parin et al. (1997) indicated that the border between the IndoWest Pacific (IWP) and Eastern Pacific (EP) provinces is situated at approximately $84^{\circ} \mathrm{W}$ on the Sala y Gómez and Nazca Seamounts. In the North Pacific, this border can be situated at Clipperton, with $43 \%$ of the decapods and stomatopods of that atoll in common with the IWP versus $57 \%$ from the EP (Poupin et al. 2008 [widespread and endemic species not considered in these percentages]). Compared with Clipperton, the Galápagos are more strongly linked to the EP, with only $10 \%$ of their decapods and stomatopods of IWP affinity. The Clipperton/Galápagos and Hawaiian Islands/French Polynesia/Easter 


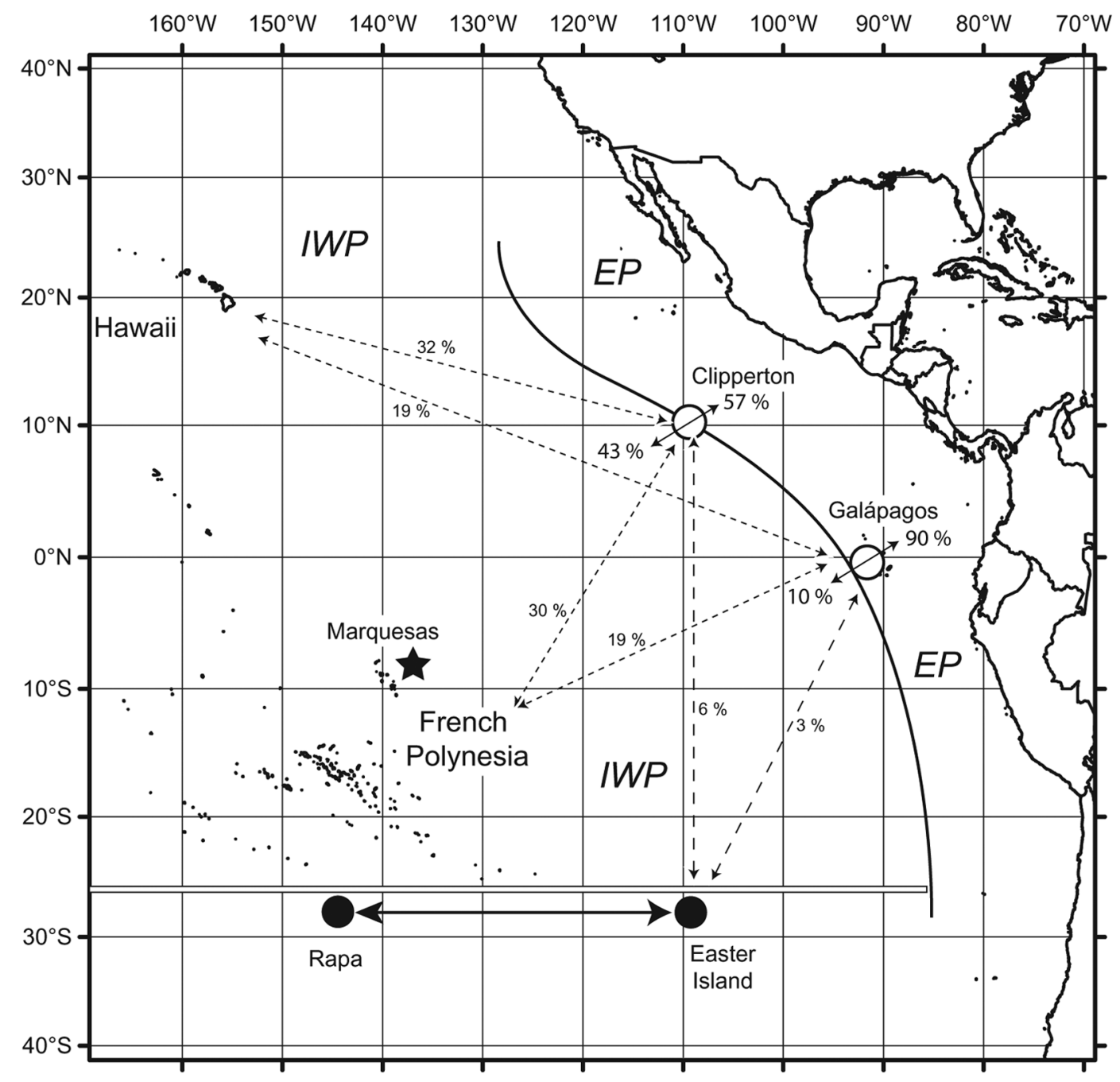

Figure 3. Partial biogeographic results obtained in the central and eastern Pacific for Decapoda and Stomatopoda. Indo-West Pacific (IWP) and East Pacific (EP) faunistic provinces are separated by an imaginary line. For Clipperton and the Galápagos, solid lines with arrows and bold percentages indicate percentage of species of IWP and EP origin; dashed lines with arrows indicate percentage of species in common between Clipperton/Galápagos Islands and Hawaiian Islands/French Polynesia/Easter Island. Star on the Marquesas Archipelago indicates a tendency to endemism. Double line below $25^{\circ} \mathrm{S}$ indicates a faunistic change. Solid line with arrows between Rapa and Easter Islands indicates faunistic affinities.

Island links are indicated on Figure 3 as the number of species in common between these areas. They confirm that the Clipperton fauna is more IWP in its composition (32\% of species in common with the Hawaiian Islands and 30\% with French Polynesia) than the Galápagos (19\% of species in common with the Hawaiian Islands and French Polynesia). Both Clipperton and the Galápagos have a weak faunistic link with Easter Island (6\% and $3 \%$ of species in common, respectively), which confirms that Easter Island 
is part of a distinct faunistic region in the southern Pacific.

\section{ACKNOWLEDGMENTS}

The organizing committee of the Tropical Island Ecosystems and Sustainable Development workshop held at Moorea, 2-7 December 2006, supported this work. Funding for the trip was provided by Professor Makoto Tsuchiya, University of the Ryukyus, Nishihara, Okinawa, Japan. Accommodation at the Moorea CRIOBE Research Station was provided by Professor René Galzin, UMS 2978 CNRS-EPHE, Ecosystèmes Coralliens, Université de Perpignan, France. Alcino Ferreira, French Navy School, Brest, proofread a first draft of the manuscript. Two anonymous reviewers helped to improve the final presentation of this work.

\section{Literature Cited}

Ahyong, S. T. 2002a. A new species and new records of Stomatopoda from Hawaii. Crustaceana (Leiden) 75 (6): 827-840.

- 2002b. Stomatopoda (Crustacea) from the Marquesas Islands: Results of the MUSORSTOM 9. Zoosystema 24 (2): 347-372.

Australian Biological Resources Study (ABRS). 2007. ABRS Fauna Online (http://www.deh.gov.au/biodiversity/abrs/ online-resources/fauna/). Accessed 14 July 2007.

Castro, P. 1999. Biogeography of trapeziid crabs (Brachyura, Trapeziidae) symbiotic with corals and other cnidarians. Pages 65-75 in J. C. von Vaupel Klein and F. R. Schram, eds. The biodiversity crisis and Crustacea. Proceedings, 4th International Crustacean Congress, Amsterdam, 20-24 July 1998. A. A. Balkema, Rotterdam.

Davie, P. J. F. 2002a. Crustacea: Malacostraca: Phyllocarida, Hoplocarida, Eucarida (Part 1). [Hoplocarida coauthored with Shane Ahyong]. In A. Wells and W. W. K. Houston, eds. Zoological catalogue of Australia 19 (3A). CSIRO Publishing, Melbourne. 2002b. Crustacea: Malacostraca: Eucarida (Part 2): Decapoda-Anomura, Brachyura. In A. Wells and W. W. K. Houston, eds. Zoological catalogue of Australia 19 (3B). CSIRO Publishing, Melbourne.

De Grave, S. 2001. Biogeography of IndoPacific Pontoniinae (Crustacea, Decapoda): A PAE analysis. J. Biogeogr. 28:1239-1253.

Eldredge, L. G., and R. C. DeFelice. 2002. Checklist of the marine invertebrates of the Hawaiian Islands. Hawai'i Biological Survey, Bishop Museum, Honolulu, Hawai'i (http://www2.bishopmuseum.org/ HBS/invert/list_home.htm). Accessed 14 July 2007.

Garth, J. S. 1991. Taxonomy, distribution, and ecology of Galápagos Brachyura. Pages 123-145 in M. J. James, ed. Galápagos marine invertebrates. Plenum, New York.

Glynn, P. W., J. E. N. Veron, and G. M. Wellington. 1996. Clipperton Atoll (eastern Pacific): Oceanography, geomorphology, reef-building coral ecology and biogeography. Coral Reefs 15:71-99.

Guérin-Méneville, F. E. 1829-1830. Atlas. In Voyage autour du monde, exécuté par ordre du roi, sur la corvette La Coquille, pendant les années 1822, 1823, 1824 et 1825. Arthus Bertrand, libraire éditeur, rue de Hautefeuille, no. 23, Paris, crustacés: pl. 1-5.

Hernández Aguilera, J. L. 2002. Crustáceos del Arquipélago de Revillagigedo (Stomatopoda y Decapoda de Thalassinidea a Brachyura), Pacifico tropical oriental. Pages 301-315 in M. E. Hendrickx, ed. Contributions to the study of East Pacific crustaceans. Vol. 1. Instituto de Ciencias del Mar y Limnologia, La Universidad Nacional Autónoma de México, Mazatlán. Hickman, C. P., Jr., and T. L. Zimmerman. 2000. A field guide to the crustaceans of Galápagos: An illustrated guidebook to the common barnacles, shrimps, lobsters, and crabs of the Galápagos Islands. Sugar Spring Press, Lexington, Virginia.

McLaughlin, P. A., D. K. Camp, L. G. Eldredge, D. L. Felder, J. W. Goy, H. H. I. 
Hobbs, B. Kensley, R. Lemaitre, and J. W. Martin. 2005. Order Decapoda. Names of crustaceans. Pages 209-326 in D. Turgeon, ed. Common and scientific names of aquatic invertebrates of the United States and Canada. Am. Fish. Soc. Spec. Publ. 31.

Miyake, S. 1999. Japanese crustacean decapods and stomatopods in color. Vol. 1. Macrura, Anomura and Stomatopoda. 3rd printing. Hoikusha Publishing Co., Osaka [in Japanese].

Motteler, L. S. 1986. Pacific island names: A map and name guide to the new Pacific. Bishop Mus. Misc. Publ. 34:1-91.

Parin, N. V., A. N. Mironov, and K. N. Nesis. 1997. Biology of the Nazca and Sala y Gómez submarine ridges, an outpost of the Indo-West Pacific fauna in the eastern Pacific ocean: Composition and distribution of the fauna, its communities and history. Adv. Mar. Biol. 32:145-242.

Paulay, G., R. Kropp, P. K. L. Ng, and L. G. Eldredge. 2003. The crustaceans and pycnogonids of the Mariana Islands. Micronesica 35-36:456-513.

Poore, G. 2004. Marine decapod Crustacea of southern Australia: A guide to identification. CSIRO Publishing, Collingwood, Australia.

Poupin, J. 1996. Crustacea Decapoda of French Polynesia (Astacidea, Palinuridea, Anomura, Brachyura). Atoll Res. Bull. 442:1-114.

- 1998. Crustacea Decapoda and Stomatopoda of French Polynesia (Dendrobranchiata, Stenopodidea, Caridea, Thalassinidea, and Stomatopoda, with additions to Astacidea, Palinuridea, Anomura, and Brachyura). Atoll Res. Bull. 451:1-62.

. 2003. Crustacea Decapoda and Stomatopoda of Easter Island and surrounding areas: A documented checklist with historical overview and biogeographic comments. Atoll Res. Bull. 500:1-50.

- 2007. Database of Crustacea (Decapoda and Stomatopoda) from central Pacific
Islands (French Polynesia, Pitcairn, Easter Island, Clipperton) (http://decapoda.free.fr mirror site http://decapoda.ecole-navale .fr/). Accessed 14 July 2007.

Poupin, J., J.-M. Bouchard, L. Albenga, R. Cleva, M. Hermozo-Salazar, and V. Solís-Weiss. 2008. Les Crustacés de l'atoll de Clipperton, inventaire, écologie, et zoogéographie (Decapoda, Stomatopoda). In L. Charpy, ed. Clipperton: Environnement et biodiversité d'un microcosme océanique. Patrimoines Naturels, Muséum National d'Histoire Naturelle, Paris (in press).

Randall, J. E. 1998. Zoogeography of shore fishes of the Indo-Pacific region. Zool. Stud. 37 (4): 227-268.

Rehder, H. 1980. The marine mollusks of Easter Island (Isla de Pascua) and Sala y Gómez. Smithson. Contrib. Zool. 289:1167.

Robertson, D. R., and G. R. Allen. 1996. Zoogeography of the shore fishes fauna from Clipperton Atoll. Coral Reefs 15:121-131.

Sakai, K. 2004. Crabs of Japan (with P. Davie, D. Guinot, and M. Türkay as contributors). ETI CD-ROM series, ISBN 90-75000-59-6.

Van Wormhoudt, A. 2008. Existence de sousespèces d'Alpheus lottini à Clipperton. In L. Charpy, ed. Clipperton: Environnement et biodiversité d'un microcosme océanique. Patrimoines Naturels, Muséum National d'Histoire Naturelle, Paris (in press).

Veron, J. E. N. 1993. A biogeographic database of hermatypic corals: Species of the central Indo-Pacific, genera of the world. Aust. Inst. Mar. Sci. Monogr. Ser. 10:1433.

Williams, S. T., N. Knowlton, and L. A. Weigt. 1999. Indo-Pacific molecular biogeography of the coral-dwelling snapping shrimp Alpheus lottini (Decapoda: Caridea: Alpheidae). Pages 195-206 in C. R. C. Sheppard and M. R. D. Seaward, eds. Ecology of the Chagos Archipelago. Occas. Publ. Linn. Soc. Lond. 2. 
